\title{
PENGARUH DUKUNGAN SOSIAL TERHADAP TINGKAT KECEMASAN IBU \\ HAMIL DI RUMAH SAKIT BERSALIN PEMERINTAH KOTA MALANG
}

\author{
Yohanes Didhi Christianto Utomo, Sudjiwanati \\ Alumni Fakultas Psikologi Universitas Wisnuwardhana Malang \\ didhi.cu@gmail.com
}

\begin{abstract}
ABSTRAK: Kehamilan merupakan saat-saat yang dinantikan oleh seorang wanita yang telah menikah dan bagi seorang wanita kehamilan merupakan suatu bentuk perwujudan kesempurnaan karena akan mendapatkan keturunan. Dalam proses kehamilan terjadi perubahan secara biologi, fisiologi dan psikologi. Secara psikologi, wanita hamil dapat mengalami stres dan kecemasan yang diakibatkan oleh proses adaptasi wanita terhadap kehamilannya. Kecemasan yang dialami oleh wanita hamil dapat mempengaruhi perkembangan janin, tekanan darah tinggi dan sesak nafas dan bila tidak segera ditangani dapat membahayakan ibu dan janinnya. Dukungan sosial merupakan suatu bentuk bantuan yang diberikan kepada individu untuk melindunginya dari konsekuensi stres. Bentuk dukungan sosial dapat berupa dukungan emosional, dukungan penghargaan, dukungan instrumental dan dukungan informasi. Dukungan sosial diharapkan dapat membantu wanita hamil menghadapi kecemasan selama proses kehamilan. Penelitian dilakukan dengan mengambil sampel sebanyak 45 wanita hamil yang memeriksakan diri di Rumah Sakit Bersalin Pemerintah Kota Malang. Metode penelitian menggunakan Skala Linkert, dan hasilnya di analisa dengan menggunakan program IBM SPSS versi 20. Hasil analisa regresi linier menunjukkan bahwa $\mathrm{F}$ hitung sebesar 7,360 $>\mathrm{F}$ tabel sebesar 7,26 yang berarti bahwa ada pengaruh dukungan sosial terhadap tingkat kecemasan ibu hamil dengan nilai signifikansi $0,01(\mathrm{p}=0,01)$. Hasil uji korelasi menunjukkan adanya korelasi negatif $(\mathrm{r}=-0,311)$ yang berarti dukungan sosial yang diberikan kepada ibu hamil membuat tingkat kecemasan yang dialami ibu hamil rendah.
\end{abstract}

Kata Kunci: Kecemasan, dukungan sosial, kehamilan

ABSTRACT:Pregnancy is a desirable moment of a married woman; and pregnancy, for a woman, is an embodiment of perfection since she is going to have a descent. During the process of pregnancy, alterations do apply biologically, physiologically, and psychologically. Psychologically, pregnant women could experience stress and anxiety as a result of adaptation process toward their pregnancy. Anxiety experienced by pregnant women is able to influence fetus growth, high blood pressure, and asphyxiate, and consequently it may endanger both mother and fetus if there is no immediate medical treatment. Social support is an aid given to individual in order to protect her from stress consequences. Social supports can be emotional support, appreciation, and instrumental support as well as information support. Social support is expected to be able to help pregnant women to handle anxiety during their pregnancy. Research is conducted by taking 45 samples of pregnant women who have checked their pregnancy at Public Pregnancy Hospital administered by Malang Municipal Government. The research method uses Linkert Scale, and the result is analyzed by using IBM SPSS program version 20. Linear regression analysis result shows that $F$ valued 7,360 $>F$ table as 7,26, it means that there is an effect of social support on pregnant women's anxiety level with significant value of $0,01(p=0,01)$. The result of correlation test pictures existence of 
negative correlation $(r=-0,311)$ which means social support given to pregnant women makes pregnant women's anxiety in low level.

Keyword: Social support, anxiety, pregnancy

PENDAHULUAN

Kehamilan merupakan saat-saat yang dinantikan oleh seorang wanita yang telah menikah dan bagi seorang wanita kehamilan merupakan suatu bentuk perwujudan kesempurnaan karena akan mendapatkan keturunan. Proses kehamilan pada seorang wanita menyebabkan perubahan secara biologis, fisiologis dan psikologi. Menurut Kaplan dan Sadock (1997), wanita yang hamil mengalami perubahan biologis, fisiologis, dan psikologis yang nyata. Perubahan psikologis pada wanita hamil lebih didominasi oleh stres dan kecemasan. Stres dan kecemasan terjadi disebabkan karena adanya perubahan secara fisik seperti membesarnya perut maupun adanya perubahan sistem hormonal pada ibu hamil sehingga dapat menyebabkan emosi pada ibu hamil tidak stabil.

Proses perubahan psikologi selama kehamilan terbagi menjadi tiga fase (trisemester). Pada ketiga fase ini seorang ibu hamil dapat mengalami kecemasan secara terus menerus bila tidak mampu berdaptasi dengan segala perubahan yang terjadi. Menurut Mini (2014), perubahan secara psikologi selama kehamilan terbagi dalam tiga fase yaitu Trimester I, II, III. Pada fase pertama terjadi fluktuasi emosi sehingga dapat menyebabkan situasi tidak nyaman. Pada trisemester II kondisi psikologis ibu hamil sudah mulai stabil karena sudah mulai dapat beradaptasi dan pada trisemester III stres akan menjadi pada fase ini karena kondisi kehamilan ibu yag semakin besar dan serba salahnya posisi 


\section{PSIKOVIDYA}

ibu dan juga bayangan risiko kehamilan dan proses melahirkan.

Akibat dari proses perubahan psikologis yang terjadi pada ibu hamil adalah munculnya gangguan kecemasan. Gangguan kecemasan yang dialami oleh ibu hamil terjadi karena proses adaptasi ibu terhadap kehamilannya. Menurut Hasibuan \& Simatupang, (1999), kecemasan merupakan suatu pengalaman emosional yang timbul karena adanya ancaman yang tidak jelas penyebabnya, baik yang berasal dari luar maupun dari dalam individu. Kehamilan merupakan salah satu sumber kecemasan. Kecemasan yang mengganggu wanita hamil adalah cemas terhadap kesehatan badannya, kematian yang mungkin akan menimpanya, keadaan yang kurang menguntungkan menjelang persalinan (misalnya tidak dapat berada di rumah sakit pada waktunya) dan takut akan rasa sakit pada waktu melahirkan. Disamping itu ada kecemasan yang secara tidak langsung berhubungan dengan kehamilan misalnya, kesulitan perumahan, kesulitan ekonomi, kesulitan perkawinan, kurangnya perhatian terutama dari suami.

Gejala kecemasan bisa diamati secara fisik seperti banyak berkeringat, detak jantung yang cepat, dan juga badan yang gemetar. Gejala lain yang dapat timbul akibat kecemasan adalah gejala neurotik seperti timbulnya rasa takut, dan timbulnya rasa khawatir. Menurut Daradjat dalam Hasibuan \& Simatupang (1999), gejala kecemasan dapat diikuti dengan mual dan muntah. Dan juga gejala fisik seperti ujung-ujung jari terasa dingin, pencernaan menjadi tidak teratur, detak jantung bertambah cepat, keringat bercucuran, tidur tidak nyenyak, nafsu makan hilang, sesak nafas, dan lain sebagainya. Selain itu kecemasan dapat juga dirasakan secara psikologis kita seperti adanya rasa takut, perasaan akan ditimpa bahaya 


\section{PSIKOVIDYA}

Vol 22, No. 2, Desember 2018

atau kecelakaan, tidak mampu tidak langsung dapat melalui proses memusatkan perhatian, tidak berdaya, kehamilannya dengan lancar. Ruang rasa rendah diri, hilangnya rasa percaya lingkup dari dukungan sosial adalah diri, dan tidak tentram, dan lain lingkungan terdekat dimana ibu hamil sebagainya.

berada. Dukungan sosial dapat diberikan

Kecemasan yang dialami oleh ibu oleh suami, orang tua, saudara, teman, hamil dapat mengganggu proses tetangga, tenaga kesehatan ataupun orang kehamilan, karena tanpa disadari oleh ibu lain. Menurut Suryaningsih (2007), hamil kecemasan yang dirasakan akan ditransfer kepada bayi dalam kandungan. Gangguan medis seperti tekanan darah tinggi, sesak nafas dapat muncul akibat kecemasan yang dialami oleh ibu hamil. Menurut Diani dan Susilawati (2013), dampak buruk yang terjadi pada ibu hamil trimester ketiga akibat mengalami kecemasan yaitu preeclampsia dan premature. Akibat tersebut dapat meningkatkan Angka Kematian Ibu (AKI) dan bayi dengan Berat Badan Lahir Rendah (BBLR).

Dukungan sosial merupakan suatu bentuk dukungan yang diberikan kepada ibu hamil agar secara langsung ataupun dukungan sosial ini banyak diperoleh individu dari lingkungan sekitar, dalam hal ini lingkungan yang terdekat adalah pasangan atau suami. Sudah selayaknya pasangan memberikan semangat dan perhatian kepada istri. Dengan begitu, istri bisa kuat secara mental untuk menghadapi segala hal di masa kehamilannya. Bentuk-bentuk dukungan sosial menurut House, Watson, dan Thoits dalam Firman \& Khairani (2000), yaitu: bantuan materi, informasi, emotional support, dan dukungan penghargaan.

Beberapa penelitian yang berkaitan dengan pengaruh dukungan sosial 


\section{PSIKOVIDYA}

Vol 22, No. 2, Desember 2018

terhadap kecemasan pada ibu hamil menunjukkan bahwa bentuk-bentuk dukungan sosial yang diberikan kepada ibu hamil berpengaruh secara nyata terhadap kecemasan yang dialami oleh ibu hamil. Menurut Ramli (2003), dari hasil penelitian tentang dukungan sosial keluarga terhadap kecemasan wanita hamil pertama yang dilakukan di Balai Kesehatan Muhammadiyah Malang, menjukkan bahwa ada pengaruh yang nyata jenis dukungan keluarga terhadap kecemasan wanita hamil pertama. Data penelitian yang diperoleh menunjukkan sumbangsih efektif dukungan sosial sebesar $72,27 \%$ dengan rincian $59,22 \%$ dukungan penghargaan, 8,97\% dukungan informatif dan $4,09 \%$ dukungan emosional dan sisanya $27, \quad 73 \%$ dipengaruhi oleh faktor-faktor lain. Penelitian yang dilakukan oleh Diani dan Susilawati (2013), menunjukkan adanya pengaruh yang nyata dukungan suami terhadap istri yang mengalami kecemasan pada kehamilan trisemester tiga di Kabupaten Gianyar, dimana tingkat kecemasan kelompok ibu hamil yang tinggal dengan suami lebih rendah dari pada yang tidak tinggal dengan suaminya. Rumah Sakit Bersalin Pemerintah Kota Malang merupakan salah satu pusat kesehatan yang didirikan oleh Pemerintah Kota Malang yang didirikan untuk melayani kesehatan ibu dan anak disamping juga melayani kesehatan masyarakat pada umumnya. Kasus-kasus medis seperti tekanan darah tinggi (preeclampsia) pada ibu hamil sering dijumpai dalam pemeriksaan medis. Tekanan darah tinggi pada ibu hamil dapat disebabkan oleh perubahan fisiologis pada ibu hamil dan juga patut diwaspadai karena adanya gangguan kecemasan. Dukungan sosial yang diberikan merupakan salah satu cara yang dapat diberikan untuk meringankan kecemasan pada ibu hamil. Oleh sebab itu peneliti tertarik untuk meneliti 


\section{PSIKOVIDYA}

Vol 22, No. 2, Desember 2018

pengaruh dukungan sosial terhadap

kecemasan pada ibu hamil di Rumah

Sakit Bersalin Pemerintah Kota Malang.

Berdasarkan uraian diatas dapat

dirumuskan suatu masalah "Apakah ada

hubungan antara dukungan sosial

terhadap kecemasan pada ibu hamil di

Rumah Sakit Bersalin "PEMKOT

Malang” Malang?".

\section{Kehamilan}

Kehamilan adalah suatu masa yang

dimulai dari bersatunya sel sperma dengan sel telur (konsepsi) sampai lahirnya janin tersebut. Lama kehamilan adalah 280 hari atau 40 minggu. Masa hamil ini dibagi menjadi tri wulan atau trimester yaitu trimester I (antara 0-12 minggu), trimester II (antara 12-28 minggu), dan trimester III (antara 28-40 minggu) (Prawirohardjo, 2002).

Bobak, (2005) mendefinisikan kehamilan sebagai persatuan antara sel telur dan sel sperma, yang menandai awal suatu peristiwa yang terpisah, tetapi ada suatu rangkaian kejadian yang mengelilinginya. Kejadian-kejadian itu ialah pembentukan gamet (telur dan sperma), ovulasi (pelepasan telur), penggabungan gamet dan implantasi embrio di dalam uterus. Hanya jika semua peristiwa ini berlangsung baik, maka proses perkembangan embrio dan janin dapat dimulai.

\section{Kecemasan}

Kecemasan merupakan suatu respon dari pengalaman yang tidak menyenangkan yang sifatnya subyektif dan timbul dengan diikuti perasaan gelisah, khawatir dan takut (Lazarus, 1969).

Menurut (Hyun, 1999), kecemasan merupakan ketidakmampuan individu dalam mengendalikan emosi dan perasaan antara ketakutan dan kekhawatiran. 


\section{PSIKOVIDYA}

Maramis (1995) menyatakan

bahwa keecemasan adalah suatu ketegangan, kekhawatiran, rasa tidak aman, yang timbul sebagai akibat dari perasaan akan mengalami suatu kejadian yang tidak menyenangkan.

Freud (dalam awisol, 2005) dalam teori psikoanalisanya menyatakan bahwa kecemasan merupakan suatu bentuk fungsi ego dalam memberikan peringatan akan datangnya bahaya sehingga dapat segera dicari reaksi adaptif yang sesuai.

Menurut Nevid (2005), Kecemasan dapat menjadi reaksi emosional yang normal dibeberapa situasi, tetapi tidak disituasi lain. Senada dengan hal tersebut, Sumadinata (2004) mengatakan bahwa seseorang yang merasa khawatir karena menghadapi situasi yang tidak bisa memberikan jawaban yang jelas, tidak bisa mengharapkan sesuatu pertolongan, dan tidak ada harapan yang jelas akan mendapatkan hasil. Kecemasan dan kekhawatiran yang ringan dan menjadi sebuah motivasi, sedangkan kecemasan dan kekhawatiran yang kuat dan negatif dapat menimbulkan gangguan fisik maupun psikis.

Berdasarkan uraian diatas dapat disimpulkan bahwa kecemasan merupakan suatu perasaan yang tidak menyenangkan, gelisah dan ketakutan yang merupakan bagian dari fungsi ego dalam memberikan peringatan akan datangnya bahaya agar dapat dicarikan reaksi adaptif yang sesuai.

\section{Faktor-faktor yang menyebabkan}

kecemasan

Faktor-faktor penyebab kecemasan dapat digolongkan menjadi:

a. Faktor Kognitif. McMahon (1986) menyatakan bahwa kecemasan merupakan akibat dari antisipasi harapan akan situasi yang menakutkan dan pernah menimbulkan suatu keadaan yang menimbulkan rasa sakit, sehingga 


\section{PSIKOVIDYA}

Vol 22, No. 2, Desember 2018

apabila suatu peristiwa yang sama

terjadi maka individu akan

merasakan kecemasan sebagai reaksi

atas adanya bahaya.

b. Faktor Lingkungan. Faktor yang dapat menjadi penyebab munculnya kecemasan adalah lingkungan, dimana kecemasan tersebut berasal dari hubungan-hubungan dan ditentukan langsung oleh kondisikondisi, adat-istiadat, dan nilai-nilai dalam masyarakat. Kecemasan dalam kadar terberat dirasakan sebagai akibat dari perubahan sosial yang amat cepat, dimana tanpa persiapan yang cukup, seseorang tiba-tiba saja sudah dilanda perubahan dan terbenam dalam situasi-situasi baru yang terus menerus berubah. Dimana perubahan ini merupakan peristiwa yang mengenai seluruh lingkungan kehidupan, maka seseorang akan sulit membebaskan dirinya dari pengalaman yang mencemaskan ini (Slavson, 1987).

c. Faktor Proses Belajar. Menurut Mowrer (dalam Goldstein\&Krasner, 1988) kecemasan timbul sebagai akibat dari proses belajar. Manusia mempelajari respon terhadap stimulus yang memperingatkan adanya peristiwa berbahaya dan menyakitkan yang akan segera terjadi.

Kecemasan menurut Collins (dalam Susabda, 1983) muncul karena disebabkan oleh beberapa faktor:

a. Threat (Ancaman) baik ancaman terhadap tubuh, jiwa atau psikisnya (seperti kehilangan kemerdekaan, kehilangan arti kehidupan) maupun ancaman terhadap eksistensinya (seperti kehilangan hak).

b. Conflik (Pertentangan) yaitu karena adanya dua keinginan yang keadaannya bertolak belakang, hampir setiap dua konflik, dua 
alternatif atau lebih yang masingmasing yang mempunyai sifat approach dan avoidance.

c. Fear (Ketakutan) kecemasan sering timbul karena ketakutan akan sesuatu, ketakutan akan kegagalan menimbulkan kecemasan, misalnya ketakutan akan kegagalan dalam mengahadapi ujian atau ketakutan akan penolakan menimbulkan kecemasn setiap kali harus berhadapan dengan orang baru.

d. Unfulled Need (Kebutuhan yang tidak terpenuhi) kebutuhan manusia begitu kompleks dan bila ia gagal untuk memenuhinya maka timbullah kecemasan.

\section{Aspek Kecemasan}

Kecemasan yang dialami oleh seseorang dapat dilihat melalui gejalagejala yang tampak maupun lewat pemeriksaan psikologi. Gejala-gejala tersebut dapat dikelompokkan dalam aspek-aspek seperti aspek fisik dan aspek kognitif. Menurut Greenberger \& Padesky (2004), kecemasan dapat berasal dari dua aspek yaitu :

1) Aspek kognitif, yang meliputi :

a. Kecemasan disertai dengan persepsi bahwa seseorang sedang berada dalam bahaya atau terancam atau rentan dalam hal tertentu, sehingga gejala fisik kecemasan membuat seseorang siap merespon bahaya atau ancaman yang menurutnya akan terjadi.

b. Ancaman tersebut bersifat fisik, mental atau sosial, diantaranya adalah:

1) Ancaman fisik terjadi ketika seseorang percaya bahwa ia akan terluka secara fisik.

2) Ancaman mental terjadi ketika sesuatu membuat 
khawatir bahwa dia akan menjadi gila atau hilang igatan.

3) Ancaman sosial terjadi ketika seseorang percaya bahwa ia akan ditolak, dipermalukan, merasa malu atau dikecewakan.

c. Persepsi ancaman berbedabeda untuk setiap orang. Sebagian orang, karena pengalaman mereka bisa terancam dengan begitu mudahnya dan akan lebih sering cemas. Orang lain mungkin akan memiliki rasa aman dan keselamatan yang lebih besar. Tumbuh dilingkungan yang kacau dan tidak sabil bisa membuat seseorang menyimpulkan bahwa dunia dan orang lain selalu berbahaya. d. Pemikiran tentang kecemasan berorientasi pada masa depan dan sering kali memprediksi malapetaka. Pemikiran tentang kecemasan sering dimulai dengan "Bagaimana kalau..." dan berakhir dengan hal yang kacau. Pemikiran tentang kecemasan juga sering meliputi citra tentang bahaya. Pemikiran-pemikiran ini semua adalah masa depan dan semuanya memprediksi hasil yang buruk.

2) Aspek kepanikan

Panik muncul karena adanya perasaan cemas atau takut yang ekstrem. Rasa panik merupakan gabungan atau kombinasi emosi dan gejala fisik yang berbeda. Seringkali rasa panik ditandai dengan adanya perubahan sensasi fisik atau mental, dalam diri seseorang yang menderita gangguan panik, terjadi lingkaran 
setan saat gejala-gejala fisik, emosi, dan pemikiran saling berinteraksi dan meningkat dengan cepat. Pemikiran ini menimbulkan ketakutan dan kecemasan serta merangsang keluarnya adrenalin. Pemikiran yang katastrofik dan reaksi fisik serta emosional yang lebih intens yang terjadi bias menimbulkan dihindarinya aktivitas atau situasi saat kepanikan telah terjadi sebelumnya.

Senada dengan hal tersebut Nevid Jeffrey S, Spencer A, \& Greene Beverly (2005), membagi gejala kecemasan menjadi tiga yaitu:

a. Gejala fisik dari kecemasan antara lain: kegelisahan, anggota tubuh bergetar, banyak berkeringat, sulit bernafas, jantung berdetak kencang, merasa lemas, panas dingin, mudah marah atau tersinggung. b. Gejala behavioral dari kecemasan ditandai dengan berperilaku menghindar, terguncang, melekat dan dependen.

c. Gejala kognitif dari kecemasan yaitu : khawatir tentang sesuatu, perasaan terganggu akan ketakutan terhadap sesuatu yang terjadi dimasa depan, keyakinan bahwa sesuatu yang menakutkan akan segera terjadi, ketakutan akan ketidakmampuan untuk mengatasi masalah, pikiran terasa bercampur aduk atau kebingungan, sulit berkonsentrasi.

\section{Jenis-Jenis Kecemasan}

Kecemasan merupakan gangguan yang bersumber dari dalam diri individu sebagai bentuk respon terhadap ancaman terhadap egonya. Menurut Kartono Kartini (2006) membagi kecemasan menjadi dua jenis, yaitu : 
1) Kecemasan Ringan

Kecemasan ringan dibagi menjadi dua kategori yaitu ringan sebentar dan ringan lama. Kecemasan ini sangat bermanfaat bagi perkembangan kepribadian seseorang, karena kecemasan ini dapat menjadi suatu tantangan bagi seorang individu untuk mengatasinya. Kecemasan ringan yang muncul sebentar adalah suatu kecemasan yang wajar terjadi pada individu akibat situasi-situasi yang mengancam dan individu tersebut tidak dapat mengatasinya, sehingga timbul kecemasan. Kecemasan ini akan bermanfaat bagi individu untuk lebih berhati-hati dalam menghadapi situasisituasi yang sama di kemudian hari. Kecemasan ringan yang lama adalah kecemasan yang dapat diatasi tetapi karena individu tersebut tidak segera mengatasi penyebab munculnya kecemasan, maka kecemasan tersebut akan mengendap lama dalam diri individu.
2) Kecemasan Berat

Kecemasan berat adalah kecemasan yang terlalu berat dan berakar secara mendalam dalam diri seseorang. Apabila seseorang mengalami kecemasan semacam ini maka biasanya ia tidak dapat mengatasinya. Kecemasan ini mempunyai akibat menghambat atau merugikan perkembangan kepribadian seseorang. Kecemasan ini dibagi menjadi dua yaitu kecemasan berat yang sebentar dan lama. Kecemasan yang berat tetapi munculnya sebentar dapat menimbulkan traumatis pada individu jika menghadapi situasi yang sama dengan situasi penyebab munculnya kecemasan. Sedangakan kecemasan yang berat tetapi munculnya lama akan merusak kepribadian individu. Hal ini akan berlangsung terus menerus bertahuntahun dan dapat meruak proses kognisi individu. Kecemasan yang berat dan lama akan menimbulkan berbagai macam penyakit seperti darah tinggi, tachycardia 


\section{PSIKOVIDYA}

Vol 22, No. 2, Desember 2018

(percepatan darah), excited (heboh, gempar).

Menurut Menurut Freud (dalam

Maramis, 19), kecemasan dibagi menjadi

tiga macam, yakni :

1) Kecemasan objektif atau Kenyataan.

Kecemasan obyektif adalah suatu pengalaman perasaan sebagai akibat pengamatan suatu bahaya dalam dunia luar. Bahaya adalah sikap keadaan dalam lingkungan seseorang yang mengancam untuk mencelakakannya. Pengalaman bahaya dan timbulnya kecemasan mungkin dari sifat pembawaan, dalam arti kata bahwa seseorang mewarisi kecenderungan untuk menjadi takut kalau ia berada di dekat dengan benda- benda tertentu atau keadaan tertentu dari lingkungannya.

2) Kecemasan Neurotis (saraf)

Kecemasan ini timbul karena pengamatan tentang bahaya dari naluriah. Freud sendiri membagi kecemasan ini menjadi 3 bagian : a. Kecemasan yang timbul karena penyesuaian diri dengan lingkungan. Kecemasan semacam ini menjadi sifat dari seseorang yang gelisah, yang selalu mengira bahwa sesuatu yang hebat akan terjadi.

b. Bentuk ketakutan yang tegang dan irasional (phobia). Sifat khusus dari pobia adalah bahwa, intensitif ketakutan melebihi proporsi yang sebenarnya dari objek yang ditakutkannya. seperti contoh kasus yang saya alami, bahwa setiap melihat atau bahkan menuliskan buah "nanas", maka bulu kuduk saya akan berdiri dan merinding dibuatnya.

c. Reaksi gugup atau setengah gugup, reaksi ini munculnya secara tiba-tiba tanpa adanya provokasi yang tegas.

3) Kecemasan Moral 


\section{PSIKOVIDYA}

Vol 22, No. 2, Desember 2018

Kecemasan moral disebabkan karena

pribadi seseorang. Tiap pribadi memiliki

bermacam macam emosi antar lain: iri,

benci, dendam, dengki, marah, gelisah,

dan lain lain. Sifat sifat seperti itu adalah

sifat sifat yang tidak terpuji, bahkan

mengakibatkan manusia akan merasa

khawatir, takut, cemas, gelisah dan putus

asa.

\section{Dukungan Sosial}

Definisi dukungan sosial menurut Rook (1985, dalam Smet, 1994) adalah salah satu fungsi pertalian sosial yang menggambarkan tingkat dan kualitas umum dari hubungan interpersonal yang akan melindungi individu dari konsekuensi stres. Dukungan sosial yang diterima dapat membuat individu merasa tenang, diperhatikan, timbul rasa percaya diri dan kompeten. Tersedianya dukungan sosial akan membuat individu merasa dicintai, dihargai dan menjadi bagian dari kelompok. Hal senada juga diungkapkan oleh Diamtteo (1991) yang

mendefinisikan dukungan sosial sebagai

dukungan atau bantuan yang berasal dari

orang lain seperti teman, tetangga, teman kerja dan orang- orang lainnya.

Menurut Rook (1985, dalam Smet, 1994) dukungan sosial merupakan salah satu fungsi dari pertalian sosial yang dapat menjadi gambaran dari tingkat dan kualitas umum suatu hubungan interpersonal yang menjadi pelindung individu dari konsekuensi stres. Dukungan sosial yang diterima oleh individu dapat menimbulkan rasa tenang, diperhatikan, rasa percaya diri dan kompeten. Adanya dukungan sosial membuat individu merasa dicintai, dihargai dan menjadi bagian dari kelompok.

\section{Klasifikasi Dukungan Sosial}

Klasifikasi Dukungan Sosial menurut Cohen \& Syme (1985) ada 4 kategori yaitu : 


\section{PSIKOVIDYA}

Vol 22, No. 2, Desember 2018

1. Dukungan informasi, yaitu suatu bentuk dukungan dengan memberikan penjelasan, informasi tentang situasi dan segala sesuatu yang berhubungan dengan masalah yang sedang dihadapi individu.

Dukungan ini dapat berupa nasehat, petunjuk, masukan atau penjelasan bagaimana seseorang bersikap.

2. Dukungan emosional, yaitu dukungan yang melibatkan empati dari individu seperti mendengarkan, bersikap terbuka, menunjukkan sikap dapat dipercaya, mau memahami, ekspresi kasih sayang dan perhatian. Dukungan emosional dapat membuat seseorang merasa berharga, nyaman, aman, dan disayangi.

3. Dukungan instrumental adalah dukungan yang diberikan secara langsung, bersifat fasilitas atau materi misalnya menyediakan fasilitas yang diperlukan, misalnya meminjamkan uang, memberikan makanan, permainan atau bantuan yang lain.

4. Dukungan appraisal atau penilaian, dukungan ini bisa terbentuk penilaian yang positif, penguatan (pembenaran) untuk melakukan sesuatu, umpan balik atau menunjukkan perbandingan sosial yang membuka wawasan seseorang yang sedang dalam keadaan stres.

$$
\text { Menurut Wangmuba (2009) }
$$

dukungan sosial mencakup dukungan informasi berupa saran nasehat, dukungan perhatian atau emosi berupa kehangatan, kepedulian dan empati, dukungan instrumental berupa bantuan meteri atau finansial dan penilaian berupa penghargaan positif terhadap gagasan atau perasaan orang lain.

Menurut Sarafino dalam Oktavia, L (2002) dukungan sosial terdiri dari empat jenis yaitu :

1. Dukungan emosional. 
Dukungan ini melibatkan ekspresi rasa empati dan perhatian terhadap individu, sehingga individu tersebut merasa nyaman, dicintai dan diperhatikan. Dukungan ini meliputi perilaku seperti memberikan perhatian dan afeksi seta bersedia mendengarkan keluh kesah orang lain.

2. Dukungan penghargaan.

Dukungan ini melibatkan ekspresi yang berupa pernyataan setuju dan penilaian positif terhadap ide-ide, perasaan dan performa orang lain.

3. Dukungan instrumental.

Bentuk dukungan ini melibatkan bantuan langsung, misalnya yang berupa bantuan finansial atau bantuan dalam mengerjakan tugastugas tertentu.

4. Dukungan informasi.

Dukungan yang bersifat informasi ini dapat berupa saran, pengarahan dan umpan balik tentang bagaimana cara memecahkan persoalan.

Berdasarkan uraian diatas dapat disimpulkan bahwa bentuk-bentuk dukungan sosial dapat berbentuk dukungan informatif, dukungan emosional, dukungan instrumental, dan dukungan yang berkaitan dengan pemberian nilai positif. Pemberian dukungan sosial ini pada dasarnya adalah untuk membantu seseorang agar dapat merasa diterima, nyaman, diperhatikan, dicintai sehingga dapat membantu dalam mengatasi masalahnya.

\section{Faktor-Faktor yang Mempengaruhi Dukungan Sosial}

Faktor-faktor yang mempengaruhi dukungan sosial menurut Stanley (2007), adalah:

1. Kebutuhan fisik

Kebutuhan fisik dapat mempengaruhi dukungan sosial. Adapun kebutuhan fisik meliputi 
sandang, pangan dan papan. Apabila

seseorang tidak tercukupi kebutuhan

fisiknya maka seseorang tersebut

kurang mendapat dukungan sosial.

2. Kebutuhan sosial

Dengan aktualisasi diri yang baik maka seseorang lebih kenal oleh masyarakat daripada orang yang tidak pernah bersosialisasi di masyarakat. Orang yang mempunyai aktualisasi diri yang baik cenderung selalu ingin mendapatkan pengakuan di dalam kehidupan masyarakat. Untuk itu pengakuan sangat diperlukan untuk memberikan penghargaan.

3. Kebutuhan psikis

Dalam kebutuhan psikis seperti rasa ingin tahu, rasa aman, perasaan religius, tidak mungkin terpenuhi tanpa bantuan orang lain. Seseorang yang sedang menghadapi masalah baik ringan maupun berat, maka orang tersebut akan cenderung mencari dukungan sosial dari orangorang sekitar.

Menurut Myers (2008), ada 4 faktor yang dapat menyebabkan terbentuknya dukungan sosial, yaitu:

1. Empati dimana kemampuan dan kecenderungan berempati kepada individu lain merupakan motif utama dalam tingkah laku yang mendorong individu. Rasa empati membuat seseorang ikut serta mengalami emosi yang dialami orang lain. Denga berempati seseorang dapat memberikan motivasi orang lain untuk mengurangi masalah yang sedang dihadapi seseorang.

2. Norma yang diterima oleh seseorang selama pertumbuhan dan perkembangan pribadi dari pengalaman bersosialisasi, mengarahkan seseorang untuk bertingkah laku secara tepat dan mengharuskan individu untuk menjalankan kewajiban-kewajiban 
dalam kehidupan sosial. Hal tersebut akan membentuk kepedulian untuk memberikan pertolongan kepada individu lain.

3. Pertukaran Sosial, dalam teori pertukaran sosial dijelaskan adanya interaksi manusia yang berpedoman pada ekonomi sosial, yaitu adanya reward dan ganti rugi dengan cara memberi dan menerima. Teori ini mengatakan bahwa individu mencoba untuk melakukan interaksi dengan memaksimalkan reward dan meminimalkan beban sehingga dapat digunakan untuk meramalkan tingkah laku individu lain.

4. Sosiologi, teori ini merupakan aplikasi dari prinsip evolusi, dimana perilaku menolong dianggap lebih menguntungkan bila dilakukan pada individu yang mempunyai hubungan darah sehingga keturunannya tetap survive daripada menolong individu lain yang dapat menghabiskan waktu dan tenaga. Jika akhirnya individu memutuskan untuk menolong individu lain, itu disebabkan karena mengharapkan bantuan yang sebaliknya dari individu yang ditolong.

\section{Hubungan Dukungan Sosial Terhadap}

\section{Tingkat Kecemasan pada Ibu Hamil}

Ibu hamil selama dalam masa

kehamilannya mengalami perubahan baik dari segi fisik maupun psikologisnya maupun kondisi lingkungan sosialnya. Selama masa kehamilannya seorang wanita akan mengalami beberapa perubahan secara fisik mulai dari perut yang terus membesar, kaki yang membengkak, susah bernapas, sering buang air kecil (Suririnah dalam Maharani, 2008). Hal tersebut diikuti oleh perubahan kondisi psikologis ibu hamil yang fluktuatif akibat perubahan sistem hormonal pada ibu hamil. Perubahan kondisi lingkungan sosialnya 


\section{PSIKOVIDYA}

Vol 22, No. 2, Desember 2018

lebih berkaitan dengan perannya sebagai seorang calon ibu, dimana wanita hamil dituntut untuk lebih matang daripada sebelum hamil (Hasibuan \& Simatupang dalam Maharani, 2008).

Dukungan sosial merupakan suatu bentuk bantuan baik secara langsung maupun tidak langsung, baik secara materi maupun non-materi yang diberikan oleh keluarga, teman, maupun orang lain untuk meringankan beban hidup seseorang. Pada ibu hamil dukungan sosial terutama dari orang terdekat yaitu suami sangat diperlukan, karena hal tersebut akan membuat ibu hamil menjadi lebih tenang dan memngurangi kecemasan selama mengandung. Menurut Ramli dalam Maharani (2008), dalam penelitiannya menarik kesimpulan bahwa ada pengaruh yang nyata dukungan sosial terhadap kecemasan ibu hamil pada trimester I. Data penelitian yang diperoleh menunjukkan sumbangsih dukungan sosial sebesar $72,27 \%$ dengan rincian $59,22 \%$ dukungan penghargaan, $8,97 \%$ dukungan informatif dan 4,09\% dukungan emosional dan sisanya $27,73 \%$ dipengaruhi oleh faktor-faktor lain. Dukungan sosial yang diterima oleh individu dapat menimbulkan rasa tenang, diperhatikan, rasa percaya diri dan kompeten. Adanya dukungan sosial membuat individu merasa dicintai, dihargai dan menjadi bagian dari kelompok.

Gangguan kecemasan dapat berakibat buruk terhadap kesehatan ibu hamil dan janinnya. Seorang ibu hamil yang mengalami kecemasan yang kronis, dapat berpengaruh langsung pada kesehatan bayi. Resiko yang kemungkinan terjadi pada wanita hamil yang menderita gangguan kecemasan adalah bayi lahir prematur yang menyebabkan berat badan si bayi rendah, bayi beresiko mengalami autism, keguguran, terlahir cacat dan mengalami 
kelainan tulang belakang, terganggunya kesehatan ibu (bidanku, 2014).

Jadi, semakin besar dukungan sosial yang diberkan kepada ibu hamil, diharapkan dapat mengurangi kecemasan yang dialami oleh ibu hamil.

\section{METODE}

Subyek yang diteliti adalah ibu hamil yang memeriksakan diri di Rumah Sakit Bersalin Pemerintah Kota Malang dengan berbagai umur kehamilan. Jumlah ibu hamil yang memeriksakan kehamilannya di Rumah Sakit Bersalin Pemerintah Kota Malang dalam sebulan rata-rata 150 orang, data diperoleh dari hasil pencatatan dan rekap buku pemeriksaan pasien.

Sampel yang diambil untuk penelitian ini berjumlah 45 orang dengan berbagai umur kehamilan. Teknik Pengambilan Sampel dalam penelitian ini adalah teknik Quota sampling, dimana sampel diambil berdasarkan jumlah ibu hamil yang memeriksakan diri pada satu hari kerja, dan pengambilan dilanjutkan pada hari berikutnya sampai jumlah kuota sampel yang diinginkan terpenuhi. Jumlah ibu hamil yang memeriksakan diri di Rumah Sakit Bersalin Pemerinta Kota Malang rata-rata per hari 5-10 orang.

\section{HASIL DAN PEMBAHASAN}

Analisis data dengan menggunakan program IBM SPSS versi 20 untuk mengetahui korelasi kedua variabel penelitian dan juga untuk menguji hipotesis. Hasil perhitungan untuk mengetahui kontribusi antara variabel dukungan sosial dengan kecemasan pada ibu hamil dapat dilihat pada table 1.

\section{Tabel. 1}

Konstribusi Variabel Dukungan Sosial Terhadap Tingkat Kecemasan pada Ibu Hamil

\begin{tabular}{|c|c|c|c|c|}
\hline Model & $\mathrm{R}$ & $\begin{array}{c}\mathrm{R} \\
\text { Square }\end{array}$ & $\begin{array}{l}\text { Adjusted } \\
\text { R Square }\end{array}$ & $\begin{array}{l}\text { Std. Error } \\
\text { of the } \\
\text { Estimate }\end{array}$ \\
\hline 1 &, $382^{\mathrm{a}}$ &, 146 &, 126 & 8,95927 \\
\hline a. $\mathrm{Pr}$ & ictors: & Constal & nt), Dukun & ganSosial \\
\hline
\end{tabular}

Adanya pengaruh dukungan sosial 


\section{PSIKOVIDYA}

terhadap tingkat kecemasan ibu hamil tidak diikuti oleh penguatan konstribusi pengaruh variabel dukungan sosial terhadap tingkat kecemasan ibu hamil. Rendahnya konstribusi variabel dukungan sosial terhadap tingkat kecemasan ibu hamil ditunjukkan oleh nilai R square (Koefisien Determinasi) sebesar $0,146(14,6 \%)$. Hal tersebut menujukkan bahwa variabel dukungan sosial hanya memberikan pengaruh konstribusi sebesar $14,6 \%$ terhadap variabel kecemasan ibu hamil dan $85,4 \%$ dipengaruhi oleh faktor lain diluar dukungan sosial.

Hasil analisa regresi linier menunjukkan bahwa nila a (constant) sebesar 117,851 , sedangkan B (koefisien regresi) sebesar 0,311. Nilai persamaan regresi yang diperoleh adalah sebagai berikut:

$$
\mathrm{Y}=117,851-0,311 * \mathrm{X}
$$

Keterangan:

$\mathrm{Y}=$ Kecemasan pada Ibu Hamil

$\mathrm{X} \quad=$ Dukungan Sosial

$$
\text { Persamaan regresi tersebut }
$$

menunjukkan bahwa skor kecemasan pada ibu hamil 117,851 dan dukungan sosial $-0,311$ dapat diprediksi bahwa ada pengaruh negatif antara dukungan sosial terhadap tingkat kecemasan pada ibu hamil yang artinya semakin tinggi dukungan sosial yang diberikan maka tingkat kecemasan pada ibu hamil akan semakin rendah.

Untuk melihat apakah analisa regresi sudah tepat dipergunakan dalam memprediksi pengaruh variabel bebas terhadap variabel terikat, maka digunakan $\mathrm{F}$ dari tabel anova yang diperoleh melalui bantuan program IBM SPSS (Statistical Product and Service Solution) versi 20 dapat dilihat pada tabel

2.

\section{Tabel.2}

Hasil Uji F Variabel Dukungan Sosial dan

\begin{tabular}{|c|c|c|c|c|}
\hline \multicolumn{5}{|c|}{ ANOVA $^{\mathrm{a}}$} \\
\hline Model & $\begin{array}{l}\text { Sum of } \mathrm{df} \\
\text { Squares }\end{array}$ & $\begin{array}{l}\text { Mean } \\
\text { Square }\end{array}$ & $\mathrm{F}$ & Sig. \\
\hline Regression & $590,768 \quad 1$ & 590,768 & 7,360 &, $010^{\mathrm{b}}$ \\
\hline 1 Residual & $3451,543 \quad 43$ & 80,268 & & \\
\hline Total & $4042,311 \quad 44$ & & & \\
\hline
\end{tabular}
Kecemasan Pada Ibu Hamil

$$
\text { Berdasarkan hasil perhitungan }
$$
diperoleh bahwa $\mathrm{F}$ hitung $>\mathrm{F}$ tabel E-ISSN: 2502-6925 


\section{PSIKOVIDYA}

Vol 22, No. 2, Desember 2018

dengan nilai signifikansi 0,01 , dimana $\mathrm{F}$

hitung sebesar 7,360 dan $\mathrm{F}$ tabel sebesar

7,26 , hal tersebut menunjukan bahwa ada

pengaruh dukungan sosial $(\mathrm{X})$ terhadap

tingkat kecemasan ibu hamil (Y) di

Rumah Sakit Bersalin Pemerintah Kota

Malang, dengan demikian hipotesis yang

berbunyi ada pengaruh dukungan sosial

terhadap tingkat kecemasan ibu hamil

diterima.

Berdasarkan hasil penelitian yang telah dilakukan di Rumah Sakit Bersalin

Pemerintah Kota Malang diketahui bahwa ada pengaruh dukungan sosial terhadap tingkat kecemasan ibu hamil, oleh sebab itu pemberian dukungan sosial terutama oleh lingkungan terdekat seperti suami dan orang tua sangat dibutuhkan oleh ibu hamil selama proses kehamilannya.

Bentuk-bentuk dukungan sosial yang diberikan baik berupa dukungan secara emosional, dukungan penghargaan, dukungan intrumental, dan dukungan informasi meskipun dalam bentuk bantuan yang sederhana akan menjadi sangat berarti bagi ibu hamil. Kebutuhan ibu hamil untuk merasa tenang, nyaman, merasa dicintai perlu mendapat perhatian supaya ibu hamil dapat lebih fokus dalam proses kehamilannya dan juga dapat meminimalkan terjadinya kecemasan.

Diani dan Susilawati (2013) menyatakan bahwa Dukungan sosial terutama dari suami merupakan faktor utama yang berpengaruh terhadap terjadinya kecemasan pada ibu hamil dalam menghadapi masa kehamilan sampai persalinan. Beberapa bentuk dukungan suami yang sangat dibutuhkan oleh ibu hamil antara lain, pelayanan yang baik, menyediakan transportasi atau dana untuk biaya konsultasi, dan menemani berkonsultasi ke dokter ataupun bidan sehingga suami dapat mengenali tanda-tanda komplikasi kehamilan dan juga kebutuhan ibu hamil. 
Pemberian dukungan sosial kepada ibu hamil tidak hanya berkaitan dengan berapa banyak dukungan yang diberikan, tetapi juga berkaitan dengan kualitas dukungan sosial yang diberikan dan penerimaan dari ibu hamil terhadap dukungan sosial yang diberikan. Kualitas dukungan sosial lebih cenderung hanya bisa dinilai oleh penerima dukungan sosial dan bersifat subyektif.

Ahyani dan Kumalasari (2012), menyatakan bahwa Dukungan sosial bukan sekedar pemberian bantuan, tetapi yang penting adalah bagaimana persepsi si penerima terhadap makna dari bantuan tersebut. Hal itu erat hubungannya dengan ketepatan dukungan sosial yang diberikan, dalam arti bahwa orang yang menerima sangat merasakan manfaat bantuan bagi dirinya karena sesuatu yang aktual dan memberikan kepuasan.

Tingkat kecemasan yang dialami oleh ibu hamil, tidak hanya dipengaruhi oleh dukungan sosial tetapi juga oleh faktor-faktor diluar dukungan sosial. Salah satu faktor yang berpengaruh adalah faktor dari dalam diri sendiri seperti kepercayaan diri, kesadaran akan segala konsekuensi kehamilannya, dan juga kesiapannya menjadi seorang ibu. Dari hasil penelitian, menunjukkan angka korelasi determinan (R Square) sebesar $14,6 \%$ yang berarti bahwa dukungan sosial berkontribusi sebesar $14,6 \%$ terhadap tingkat kecemasan ibu hamil dan $85,4 \%$ dipengaruhi oleh faktor lain diluar dukungan sosial. Hasil uji korelasi menunjukkan adanya korelasi negatif antar variabel dimana $\mathrm{R}=-0,311$, hal tersebut berarti semakin besar dukungan sosial yang diberikan maka tingkat kecemasan pada ibu hamil akan menurun.

$$
\text { Menurut Diponegoro dukungan }
$$
sosial yang diterima oleh ibu hamil akan berpengaruh bagi ibu hamil tersebut dalam mengurangi kecemasan, karena pada saat ibu hamil yakin sudah memiliki banyak teman dan ada dukungan dari 
lingkungannya, maka keyakinan untuk dapat mengurangi kecemasan akan meningkat ( Diani dan Susilawati, 2013).

\section{KESIMPULAN}

Berdasarkan hasil penelitian dan analisis data yang telah dilakukan dengan menggunakan metode regresi linier menunjukkan bahwa ada pengaruh dukungan sosial terhadap tingkat kecemasan ibu hamil di Rumah Sakit Bersalin Pemerintah Kota Malang. Dimana terdapat korelasi negatif antara kedua variabel penelitian, yang berarti bahwa apabila semakin besar dukungan sosial yang diberikan kepada ibu hamil, maka tingkat kecemasan pada ibu hamil akan menurun. Dalam penelitian ini, variabel dukungan sosial memberikan kontribusi pengaruh sebesar $14,6 \%$ terhadap tingkat kecemasan pada ibu hamil dan $85,4 \%$ dipengaruhi oleh faktor lain.

\section{DAFTAR PUSTAKA}

Ahyani, L.N., Kumalasari, F. 2012. Hubungan Antara Dukungan Sosial Dengan Penyesuaian Diri Remaja di Panti Asuhan. Jurnal Psikologi Pitutur. Volume 1 No.1, Juni 2012.

Alwisol. 2009. Psikologi Kepribadian. Malang: UMM Press.

Arikunto. 2002. Prosedur Penelitian; Suatu Pendekatan Praktek. Jakarta: PT. Rineka Cipta

Asdie, A.H.,. 1988. Stres, Kecemasan dan Penyakit Psikosomatik, symposium stress dan kecemasan. Yogyakarta: Fakultas Kedokteran UGM.

Bart, Smet. 1994. Psikologi Kesehatan. Jakarta: PT. Gramedia Widiasarana Indonesia.

Bobak. 2004. Keperawatan Maternitas. Jakarta: EGC.

Budiarto, Eko. 2004. Metode Penelitian. Jakarta: EGC.

Cohen, I.S., Syme, L.S,. 1985. Social Support And Health. San Franscisco: Academic Press.

Calvin S. Hall. 1999. A Primer of Freudian Psychology. Plume Publisher.

Dacey, J.S. 2000. Your Anxious Child: How Parents and Teachers can Relieve Anxiety in Children. San Fransisco: Jossey-Bass Publishers. 
Diani dan Susilawati. 2013. Pengaruh Dukungan Suami Terhadap Istri Yang Mengalami Kecemasan Pada Kehamilan Trimester Ketiga Di Kabupaten Gianyar. Jurnal Psikologi Udayana. Vol.1 No.1, 111.

Dimatteo, M.R. 1991. The Psychology of Health, Illness, and Medical Care. Pasific Grove, California: Brooks/Cole Publishing Company.

Duwi, P. 2014. Analisis Regresi Linier Sederhana.

http://duwiconsultant.blogspot.com 12011/11/analisis-regresi-liniersederhana.html. Diakses pada tanggal 27 Juli 2014.

Firman \& Khairani. 2000. Dukungan sosial dan penerimaan diri pedagang wanita pasar pedesaan Minangkabau dalam memberdayakan sumber ekonomi keluarga. Laporan Penelitian Kajian Wanita. Sumatra Barat: Fakultas Ilmu Pendidikan Universitas Negeri Padang.

Greenberger dan Padesky. 2004. Manajemen Pikiran Metode Ampuh MenataPikiran Untuk Mengatasi Depresi, kemarahan, Kecemasan, dan Perasaan Merusak Lainnya. Bandung: Kaifa PT. Mizan Pustaka.

Hasibuan, R \& Simatupang, N. 1999. Kecemasan pada kehamilan pertama ditinjau dari peransocial support. Laporan Penelitian. Surabaya: Departemen Pendidikan Nasional Universitas Negeri Brawijaya.

Hyun. 1999. Test anxiety and Working Memory. Journal of Experimental
Education $\quad 67 \quad$ (3): $\quad 218-240$. doi:10.1080/00220979909598354

Kartono, Kartini. 2006..Psikologi Wanita. Bandung: Mandar Maju.

Kaplan, H.I, Sadock, B.J, Grebb, J.A. 1997. Sinopsis Psikiatri edisi ke-7. Jakarta: Binarupa Aksara.

Lazarus, Richard S. 1969. Pattern of Adjustment and Human Effectivines. Newyork: Mc.GrawHill Inc.

Leonard. 2008. Pengaruh Konsep Diri, Sikap Siswa pada Matematika dan Kecemasan Siswa Terhadap Hasil Belajar Matematika (Survei pada SMP di Wilayah DKI Jakarta). Universitas Indraprasta PGRI.

Maramis, W.F. 1980. Catatan Ilmu Kedokteran Jiwa. Surabaya: Airlangga University Press.

Maharani, T.I., . 2008. Hubungan Antara Dukungan Sosial dan Kecemasan dalam Menghadapi Persalinan pada Ibu Hamil Trimester Ketiga. Skripsi. Universitas Guna Dharma.

Mini, Rose. 2014. Tiga Fase Psikologis Ibu Hamil. http://www.sehatnews.com/pregna ncy/19598-tiga-fase-psikologisibu-hamil.html . Diakses pada tanggal 19 Juli 2014.

Myers G, David. 2012. Psikologi Sosial Edisi 10. Jakarta: penerbit Salemba Humanik. 
Nevid, J.S, Rathus, S.A, Greene,B. 2005. Psikologi Abnormal Jilid I. Jakarta: Penerbit Erlangga.

Oktavia, L dan Basri, A.S. 2002. Hubungan Antara Dukungan Sosial yang Diterima Secara Nyata dengan Ada atau Tidaknya Gangguan Depresi Pasca Persalinan pada Ibu Dewasa Muda. Jurnal Psikologi Sosial. ISSN 08533997. Volume 8. Nomor 1. Halaman 15-18.

Pantikawati I, Saryono. 2010. Asuhan kebidanan I (kehamilan). Yogyakarta: Nuha Medika.

Prawirohardjo, Sarwono. 2002. Pelayanan Kesehatan Maternal dan Neonatal. Jakarta: Yayasan Bina Pustaka.

Purwaningsih W. Dan Fatmawati S. 2010. Asuhan Keperawatan Maternitas. Yogyakarta: Nuha Medika.

Rochman, K.L. 2010. Kesehatan mental. Purwokerto: Fajar media Press.

Ramli, H. 2003. Pengaruh jenis dukungan sosial keluarga terhadap kecemasan wanita hamil pertama di balai kesehatan Muhammadiyah Malang. Tesis (tidak diterbitkan). Malang:Fakultas

Psikologi JIPTUMM.

Revina. 2014. Tertekan Selama Kehamilan Menyebabkan Gangguan Perkembangan Janin. www.bidanku.com/tertekan- selama-kehamilan-menyebabkangangguan-perkembangan-janin.

Diakses pada tanggal 23 Juli 2014.

Riduwan. 2003. Dasar-dasar Statistika. Bandung: Alfabeta.

Saifuddin Azwar. 2012. Penyusunan Skala Psikologi. Yogyakarta: Pustaka Pelajar.

Santos., et al. 2006. The 2004 Pelotas birth cohort: methods and description. Jurnal Rev Saúde Pública. 2006:40(3). Di download dari

http://www.scielo.br/pdf/rsp/v40n3 /en_07.pdf

Smet, Bart. 1994. Psikologi Kesehatan. Jakarta: PT. Gramedia Widiasarana Indonesia.

Stanley. L. 2007. Buku Ajar Patologi Robbins. Edisi7. Jakarta: EGC.

Sugiyono. 2001. Metode Penelitian Administrasi. Bandung: Penerbit Alfabeta.

Sumadinata, N. 2004. Landasan Psikologi Proses Pendidikan. Bandung: PT Remaja Rosda karya (Diponegoro, 2009).

Suryabrata, Sumadi, . 1986. Psikologi Kepribadian. Jakarta: CV. Rajawali.

Suryaningsih. 2007. Tips mengatasi stres saat kehamilan. http://www.suryaningsih.wordpres s.com/2007/05/22/tips-mengatasi- 


\section{PSIKOVIDYA}

stres-saat-

kehamilan/+dukungan + sosial + unt uk+wanita+hamil. Diakses pada tanggal 22 Juli 2014.

Susabda, Yakub B. 1983. Pastoral Konseling Jilid 1 dan 2. Malang : Gandum Mas.

Sutrisno Hadi. 1982. Analisis Regresi. Yogyakarta: Andi Offset.

Sutrisno Hadi. 2000. Statistik. Yogyakarta: Andi Offset.

Taylor. S.E. 1999. Health Psychology (4th ed.). Boston: McGraw Hill.

Wangmuba.2009.Kecemasan dan

Psikologi.http://wangmuba.com/tag/kece masan. Diakses pada tanggal 22 Juni 2014. 